\title{
The Integration of Religion and Culture to Construct Social Identity Through The Pukul Sapu Ritual in Mamala Village, Moluccas
}

\author{
Flavius Floris Andries \\ Sekolah Tinggi Agama Kristen Protestan Negeri Ambon, Indonesia \\ Email: qumran_2007@yahoo.com
}

\begin{abstract}
The integration of religion and culture to build the discourse of social identity is an interesting issue. For Mamala, a village in the Moluccas, Indonesia, society consists of two embedded identities, namely religion and culture, in the construction of social identities. This research discusses religious and cultural integration in the construction of social identity by means of a flagellation ritual known as pukul sapu. This research applies qualitative methods to analyze qualitative data gathered through observation, in-depth interviews and document reviews. In particular, this research attempts to answer (a) why the pukul sapu ritual is performed by the Mamala community on the seventh day after Iedul Fitri, (b) how the ritual is carried out, (c) what elements are used in the ritual process, and (d) what meaning emerged in connection with the construction of their identity as Muslims and also as a society of customs. The research subjects consisted of a number of religious figures, customary figures, and people who are directed to participate in the review process of the ritual. This study shows that the ritual is regarded as a medium to construct the social identity (religion and culture). The integration of religion and culture in Mamala has proven that the social identity of this society includes religion and culture formed by dialectical processes, namely adaptation, relations, and negotiations between local traditions coupled with the influence of Javanese traditions. This, in fact, describes liquid social identity instead of static movement.
\end{abstract}

Keywords: religion; culture; pukul sapu; flagellation ritual; social identity construction

\section{INTRODUCTION}

Custom is a part of culture. It is also a social system that is systematically arranged and functions as a means or medium of constructing self-identity or a social group. Individual or communal identity expression towards a particular culture, which emerges in society as a custom, appears in various forms of ritual practices that have been arranged on the custom maker's (i.e. ancestor's) consensus (in Maluku they are referred to as tete nenek moyang). All forms of agreement are aimed towards binding the whole order of the custom in the society.

The efforts of maintaining and preserving the custom are the responsibility of all members of the society. On one hand, it is considered a form of respect to the ancestors, the founding fathers of the custom. On the other hand, it is also regarded as a form of obedience, since adhering to formal rules are believed to be ethical, moral, and even sacred values for the survival of the custom. In other words, obedience to the custom is a result of the assumption of the sacred element of the custom. Hence, good or bad consequences will arise in a community depending on how much obedience is given in the conduct of a custom. Generally, the Moluccan people believe 
that good consequences are understood as a blessing for obedience when performing customs. Meanwhile, illness, death, and even unproductive land and sea are assumed to be punishment for disobeying the custom's rules (Cooley, 1961).

Based on a fundamental understanding, it is mentioned that when religion came to the Moluccas, in which the village of Mamala is located, Islam was accepted as part of their social and spiritual lives. However, they still preserved their traditions, customs, and values. The religious teachings that seemed to be full of theological doctrines, such as Tauhid, were then communicated in accordance with the society's cultural values, which were the product of their ancestors, and formed to be a religious power. One example of this fusion of religion (Islam) and traditional custom in Mamala society can be seen in the pukul sapu ritual, the practice of reciprocal flagellation using sticks made from palm leaves one week after Iedul Fitri.

This specific phenomenon has spurred researchers to study the relationship between religion and culture in Mamala society, which serves to construct its identity, in order to obtain the meanings behind the ritual. Research is also driven by the fact that Mamala villagers are adherents of Islam and strongly influenced by monotheistic doctrines (teachings). ${ }^{1}$ Islam forbids the worship of anything other than Allah (God), as well as the practice of magical elements or customs in religious rituals. Mamala people, in fact, continue to submit to the demands of their religion. However, they likewise maintain their traditional practices, including the flagellation ritual, which contains magical elements and is one of a series of post-Iedul fitri religious rituals. Therefore, it can be assumed that the Mamala community has integrated religion and culture to be the means of constructing their identity both as Muslims and the preservers of local values. In general, this specific phenomenon is of the author's interest, leading to the present study.

Based on the above explanation, the construction of Mamala people's social identity through the integration of religion and culture is achieved through the pukul sapu ritual. In general, the main problem to emerge in this research regarding the pukul sapu ritual is why this religious and cultural integration occurs in Mamala considering its people are Muslims who firmly hold the Tauhid doctrine. The above problem will be elaborated in the following research questions: 1) why is the flagellation ritual performed by the Mamala villagers in its series of religious rituals following Iedul Fitri; 2) how is the ritual process carried out; 3 ) what elements are used in the ritual; and 4) what does it mean?

\section{RESEARCH METHOD}

This research was conducted using a qualitative method. To obtain the data, an ethnographic approach involving interviewing informants and observing the process of religious and cultural integration to construct a social religious identity through the pukul sapu ritual. According to Creswell (2012: 462), ethnographic designs are qualitative research procedures for describing, analyzing, and interpreting a culture-sharing group's shared patterns of behavior, beliefs, and language that develop over time. Therefore, ethnography was used in this research as an effort to acquire the data relating to historical reasons. Moreover, this approach can help the writer to explore and carry out an intellectual reflection on the historical uncertainty used to construct social religious identity, such as Mamala Oil and the ritual of reciprocal flagellation. The gathered data were analyzed by way of an interpretation process. This involved assigning meanings to the data based on explanations and analysis within the assumption that the collected data were the result of construction.

\section{FINDINGS AND DISCUSSION}

\section{The History of the Pukul Sapu Ritual}

In terms of historical development, the tradition of flagellation in Mamala has taken place since the $16^{\text {th }}$ century. After the war of Wawane and Kapahaha, the Dutch wanted the countries in the mountainous areas to descend to the coast. The Mamala community, on the mountain, at the time had converted to Islam. Thus, when the displacement of settlements occurred, one substantial need was the presence of a worshipping facility; i.e. a mosque. ${ }^{2}$ This shows that although Mamala was located on the top of the mountain, there nevertheless had been a relationship between its community and the outside world, one that was related to the religious issue; i.e. Islam, which is devoid of animist beliefs (such as worshipping a large tree or rock). In fact, they had already understood and embraced Islam.

The tradition of establishing relationships with the outside world that had become a habitus of Mamala society led them to move outside of Mamala and go to the land of Java, namely Kediri. The people then studied Islam there. ${ }^{3}$ This shows that the people of 
Mamala still have knowledge of Islamic development from Java. Moreover, Kediri in East Java became one of the places to learn Islam. In Kediri, the Islamic world, with its mosques' distinctive architectural styles, became the inspiration for the Mamala people studying Islam there in building their mosque using wood, but not using a peg on the alif (the first) pole. ${ }^{4}$

Thus, the acquired architectural style showed itself in the construction of Mamala's mosque as a symbol of its Islamic identity, the village people having experienced an influx of novel ideas from the outside world. This is in agreement with Lawler (2008: 5 ), who proposed that identity as a social product is the result of social construction and negotiation. In other words, identity is the result of the social interaction of a society. Therefore, Jenkins (2008: 17) said that identity is not something that comes from within the human self.

The idea of building a mosque in Mamala using a wooden beam without a peg was not the community's original idea, stemming instead from the knowledge they received while studying Islam in Kediri. This is in line with Berger's concept of social construction identity, which is called the dialectical process. The fundamental dialectical process of society consists of three steps: externalization, objectification, and internalization (Berger, 1994: 4). In terms of the dialectical process, as Berger mentioned, the factual condition relating to the mosque in Kediri, which uses a beam without a peg, is the objective condition that inspired the people of Mamala to build a mosque similar to the Kediri mosque. This empirical phenomenon is the adaptation of the Mamala community's traditional customs to those of Kediri in terms of mosque construction. Berger's concept also mentioned transformation that happens based on the interaction of two communities.

This transformation, which is based on the interaction process, formed the knowledge of the Mamala people and further impacted their wishes to build a mosque similar to others' ideas. The new idea that was then implemented by building the mosque using a beam and no peg does not represent the new habitus. Yet, it is understood as the cultural product, as well as the result of cultural contact or the dialectical process, which eventually manifested as the symbol of religious identity in Mamala society. The dialectical process is how to integrate external elements, i.e. Kediri's mosque's architectural style while also maintaining local elements as part of tradition. Here, we see how the identity is formed, both in relational patterns and social interaction, through the dialectical process between internal and external factors or among individuals with an outside agency. Furthermore, it shows that identity construction is a flowing, liquid process instead of static, solid activity. By this, according to Jenkins (2008: 18), argument, one can find the similarities and differences between himself and the others.

From the narrative above, the interesting aspect needs to be underlined is that Mamala's identity is represented through the mosques as the places of worship. The desire to build a mosque similar to the one in Kediri expresses that the Islamic identity of Mamala's community is not static, rigid, closed, and exclusive, but it is always open, liquid, and related to the outside world. The social interaction between Mamala people and Muslims in Kediri through education eventually influenced Mamala society's style in constructing their Islamic identity symbol in the form of a Javanese-styled mosque. This is a fact is in line with Lawler's argument that identity is part of a social product as well as the result of social relations (Lawler, 2008: 8). Moreover, Berger (1994: 4) proposed this as a dialectical process in the construction of identity, which is achieved through an externalization, objectification, and internalization process; practically converged in a long process in the history of Mamala society.

The interaction process has always produced two things such as receiving and ignoring. In this context, the interaction process with others such as the one that appears in the social religious activity in Mamala shows a process of receiving, which is clear in Mamala's decision to build a mosque like the one in Kediri. Therefore, identity is a product and it emerges in the dynamic process (Barker, 2006, van Meijl, 2004, Plumer, 1994).

In the other words, both receiving and ignoring are the result of inter-group contact. The positive values of inter-group contact between two different identities have generated empathy and solidarity in the relationship, which is apparent in the Mamala people's desire to build a mosque similar to the one in Kediri. Therefore, the process of learning Islam in Kediri describes that institutional religion i.e. Islam in Mamala village supported the people to learn from others. Moreover, Islam in Kediri was open to receiving others and served as inspiration for change. This is in line with Andries' statement (2014: 119) that religion is categorized as collective cultural identity which may be raised by interaction 
with others or outsiders. This means that the influence and the contribution of others is a goal to construct self and collective identity, and it naturally occurs in a multicultural society.

The multicultural aspect of the society, as well as the social activities of Mamala people, as mentioned above, is relevant to be discussed in terms of religious pluralism within a multicultural context. It shows that people of different ethnicities, religions, or groups live in prejudice and intolerance but they learn from cultural contact or inter-group contact. They also learn from others to foment change.

\section{The Role of Three Figures in the Construction Process of the Masjid}

The mosque, as a place of worship, became a vital necessity for Mamala, which had embraced Islam. Their experience while gaining religious knowledge in Kediri, as well as in observing the architectural style of its mosque, encouraged the Mamala villagers to build their own place of worship similar in appearance to the one they saw in Kediri. The King, Imam Tuni, and several artisans discussed the construction of mosques. They expected that the construction of their mosque would bear a resemblance to the one in Kediri. However, the wood used as the beam that would function as the alif pole or first pole for constructing the mosque was broken. As a result, they were desperate. ${ }^{5}$

The construction process of the mosque was the formation arena of the Mamala society's identity as Muslims, requiring them to bet their entire capital symbolically. Besides the economic and social capital emerging in the construction process of the mosque, cultural capital is likewise interesting to investigate. The cultural capital emerged through the construction of the mosque; i.e. the cooperation of three important figures who characterize democratic values in Mamala society. The cultural capital appeared when the King, Imam Tuni, and the artisans had equal roles and positions in the dialogue process of building the mosque. It can be seen from this process that the condition of the structure of the social arena was similar between the three figures. The King, Imam Tuni, and the artisans had similar positions in relation to their respective roles.

The three figures in this narrative represented particular identities, having different roles in the community, even though they had similar positions in the discussion related to the problem they faced.
This is in accordance with Durkheim's statement on labor division in society (Jenkins, 2008: 24). The positions of the three figures not only represent particular identities based on their roles, but the collective identity towards the crisis in which they had to discuss the prayer (or munajat) performed by Imam Tuni. The decision for the munajat also reflects the collective identity awareness since people feel an emotional bond and have the same values as other individuals or groups (cf. Hewith, 2003: 105, Andries, 2014: 118).

The dialectical process of the three figures in seeking solutions to their problems began with a deliberation process as a form of appreciation for the cultural values in their social lives. There was dialogue and compromise between the three figures that produced a consensus and division of roles according to their expertise. This shows the characteristics of Mamala's social identity as a customary and religious community upholding the values of tolerance and democracy. Here, the King did not use his autonomy to instruction the people to work out their problems; instead the social arena was used by the King and the society to create an agreement through deliberation.

The dialogue process regarding the broken beam led them to take munajat, asking God for guidance, in the hope that they would be given insight at night into potential solutions. This fact reveals that religion is never only a matter of belief. It also emerges in the form of a ritual process. Religious beliefs are expressions of the sacred and ritualized world, serving as rules of conduct for how participants should behave in the presence of sacred objects (Durkheim, 1994:34). Therefore, both religion and ritual are interrelated; religion could not stay alive without ritual, but ritual, too, could not exist without religion (Bell, 1992: 19). Munajat is a religious phenomenon as well as an expression of the symbolic communication of people's feelings and psychological condition, such as frustration because their desire has not been executed. Therefore they must carry out a munajat.

This reality, on the one hand, describes the cultural and religious integration. This represented identity occurred from the inter-group attitude of the community to encourage dialogue on the process of solving the problem. The encouragement for the dialogue demonstrates the attitude of inter-group solidarity towards the crisis. In this context, we can see that solidarity is essential for building strategies, where they support each other in group circles to find a solution to the crisis. On the other hand, this also 
shows that the inter-group solidarity opened a space to build the dialogue and finally the ritual was the path way toward solving the problem.

As a symbolic communication, munajat is also seen as the symbolic frustration of the people. In this case, O. Dea mentions that the ritual is a ceremony that expresses deep feelings in terms of psychological and subconscious feelings. Rituals have a high emotional meaning that is very complex and permanent. They also hold a functional meaning that is very important to certain people. Worship that gives honor in respect to religious terms can be used to strengthen community solidarity (O. Dea in Yusuf, 2005: 9)

Therefore, munajat clearly illustrated the sanctification dimension of religious reality, which was visibly expressed through Imam Tuni. "God" gives guidance to him in the form of "inspiration" during sleep, stating:

Hi Imam Tuni, take coconut oil, read this following verse (Qur'an, surah Al-fatiha) then smear the oil on the broken wood, then close and tie them with white cloth for a while, open back and look at what you want. ${ }^{6}$

Through the instructions delivered to Imam Tuni, we can see that religion is also considered to be an entity that has sacred values because there is a divine element. In this concept, religion is positioned as the belief in the spiritual dimension (Taylor, 1970: 9), as well as a supernatural character (Daniel 1966: 34). Similar, is Giddens's idea (2003: 452) that religion consists of a set of symbols that evoke wisdom and feelings of respect, as well as various ritual practices and ceremonies run by its community of followers.

In spite of the confidential content of the prayer, it appears that in terms of the construction process of Mamala's social identity, the ritual aspect (munajat) became one of the most essential elements. Through the munajat, Mamala society is very familiar with Islamic teachings and it becomes common practice. Munajat is carried out by surrendering to the creator both physically and mentally (Allah SWT), in the hope of receiving a reply (ref. Bell1.997).

Prayers that have a confidential character containing sacred values are known only to certain figures. Based on the narrative of the former king of Mamala, besides Imam Tuni, the King also knew the confidential prayer since, from a historical perspective, the King or "Latu Liu" was the one who instructed Imam Tuni to take munajat. Thus, besides Imam Tuni, the King was also the initial person to receive the "inspiration". However, since Imam Tuni served as the religious figure, he bore the responsibility for implementing it. ${ }^{9}$ This statement clearly expresses the role of a particular identity as what Jenkins underlines about who others are and some senses of who we are or who they are (Jenkins, 2008: 24).The statement of "who" describes the identity awareness that arises in crucial situations. Based on Jenkins's explanation of identity, which correlates to the situation in this narrative, it can be said that in the crisis faced by the Mamala people related to the process of building a mosque, the problem of identity emerged.

The other interesting problem to discuss regarding this narrative is related to the representative figure or the limitation of the people joining in the munajat process. This was the challenge faced by Mamala Muslims during the construction process of their Islamic identity, as symbolized by the mosque, and further brought them into a communication process involving the broken beam. The phenomenon illustrates the limitations of the social space mainly for the three essential elements (i.e. the King, Imam Tuni, and the artisan). The interaction process between these elements characterized a practice of the form and spread of power that was limited to certain people, namely the King and Imam Tuni.

Here, it can be seen that in any social arena, democracy, to some extent, is limited to only certain people. Although the democratic process became a choice for Mamala society, which was represented in the dialogue of the three figures, but there are certain elements that were confidential and known only to the King and Imam Tuni, with the artisan excluded despite being involved in the dialogue.

\section{The Efficacy of Mamala Oil, Presence of the Symbol of God in Human History}

The dream or the "inspiration" received by the King and Imam Tuni was then implemented. The King ordered Imam Tuni to smear oil on the broken beam and wrap it with white cloth. After a few hours, after the sun rose, they saw the miracle. The broken beam was reconnected..$^{10}$ This ameliorated the Mamala villagers' desperation and disappointment.

The reconnected beam previously smeared with "Tasalah" oil called "Mamala Oil" was a blessing given by God to Mamala. This is consistent with the narrative of the former King of Mamala, who said that:

If Allah does not approve, all efforts to build the mosques will not materialize, there would 
not be even the dream given by God and the oil is meaningless. ${ }^{11}$

This information clearly shows that the social and religious identities are closely related to the symbol of Mamala Oil, which is understood as the symbol of God Omnipotent as creator. The recognition of the Omnipotence of the Creator brought to a belief that the "Tasalah"oil was not the work of humans that contained magical powers, but instead had come from Allah SWT. Allah SWT is present in human history through various events including those experienced by Mamala society. By this, Mamala's people are convinced that faith in Islam is not something empty and valueless, but it is proven that Islam and its teachings are not in vain.

With this story, we find the meaning of the Mamala Muslims' belief in God's presence. This is in accordance with the ideas of Liliweri (2007: 179) and Maran, (2000: 43) who said that meaning can be shown with symbols. Therefore, Mamala Oil becomes an important symbol for the village, from which the people derive their belief in the omnipotence and presence of God in their religious history. Their faith in Allah is not limited to the inherited faith of religious traditions and the scripture; it appears as well in their encounters the everyday problems of life.

This is the reason for Mamala Muslims' view of Mamala Oil as an integral part of the pukul sapu ritual. Mamala Oil as part of the culture through which there are symbols and meanings describing the particular form of trust of the society. In relation to this, Geertz (1992: VI) said that cultural symbols serve as the vehicle of meaning. Geertz's thoughts are relevant to study of the sticks used to whip the body during the ritual, ${ }^{12}$ which act as the medium to prove the efficacy of Mamala Oil, the symbolic representation of Allah SWT in the history of Mamala society. Islam not only led to the people of Mamala experiencing the omnipotence of the Creator, it also proved that belief in Allah within Islam must be achieved through hard work and earnest striving, instead of through folded arms. Allah is not a magician. His presence in human history is through various real ways as well as the hard work of humans.

Based on the above narrative, it should be highlighted that faith in Allah's presence throughout human history, as had been experienced by the ancestors of today's inhabitants of Mamala, is not intended to promote or be proposed as a weapon to claim that only Islam is the true religion. This is confirmed by the argument that Allah SWT has freedom and power to declare His plan and great work to humans in diverse and various forms. The efficacy of Mamala Oil is only one of many ways that was shown by Allah SWT to confirm His power. ${ }^{13}$

Therefore, the guidance received by Imam Tuni to take oil and put it on the broken beam after reading Al-fatihah asserted that man should work and try to get something in accordance with the wishes, while leaning on God's commands. Obedience to God's commands was apparent in case when the King ordered Imam Tuni to act in accordance with the instructions he received. There are two things we can learn from such events: obedience and hard work. Taking munajat and being obedient to Allah's instructions is an uluhiyah aspect. Likewise, working in accordance with the instructions received shows an ubudiyah aspect.

The uluhiyah and ubudiyah aspects are allencompassing in both the religious and everyday lives of Mamala's Muslims. They are capable of integrating religious values with outside aspects of life that require effort and struggle. In other words, having strong faith coupled with working hard is part of Mamala's social identity, and is the result of the dialectical process between reality and expectations.

\section{Attraction of the Flagellation Stick: The Medium to Prove The Efficacy of Mamala Oil}

After Imam Tuni carried out the command of King "Latu Liu" to smear the "Tasalah" oil or Mamala Oil, the results were apparently consistent with what they wanted. Then, there was a desire to test the efficacy by asking a human. This desire was motivated by the fact that the "inspiration" they received was not only associated with the broken beam, but also human bone fractures, or kaseleo. ${ }^{14}$

The decision to use a stick made from a palm leaf to prove the efficacy of Mamala Oil could have been prompted by several factors, such as:

According to Mr. Jalal, in the past, this type of stick was used to educate children because when it is struck on one's body, it will be very painful and even result in bleeding. ${ }^{15}$ There is also another opinion that the use of the stick as the tool to test the efficacy of Mamala Oil was because in ancient times the King of Mamala had attempted to persuade his daughter Fatimah to stop crying using various methods, 
but all failed to succeed. Only after he showed the stick did the child stop crying. ${ }^{16}$ There is also another opinion that states that the use of the stick to test the efficacy of Mamala Oil was because the ancestors considered it to originate from an auspicious plant. There is, nonetheless, a formidable force, such as the example of using the stick to whip someone that can apparently result in tremendous pain and bleeding. ${ }^{17}$

From the above description, it is apparent that there are different versions of the narrative related to the reasons for using sticks made from palm leaves to test the efficacy of Mamala Oil. However, the researcher saw an interesting thing as the core for using this type of stick, in that it is small in size yet sturdy and flexible. It will not break when it makes contact with the human body, but inversely will cause injury. The pukul sapu ritual is an act of employing the human body as the object to show the efficacy of Mamala Oil. Therefore, the body is an important part of the performance. Butler (2004: 198-199) mentions that this performance is not merely about speech; it also requires physical acts. Butler's argument is to explain that performance represents someone's desire to do something by speech, as well as by the actions of the body. It also has the active role to convince function and meaning because body possesses discourse history of the same performance which had been the elements in the past (Butler, 1990: 95).

Based on Butler's argument above, it can be understood that the flagellation ritual performed by the youth in Mamala in fact results in an injured body, and even triggers bleeding. However, after the stricken area is rubbed with Mamala Oil, it will appear to dry within a few days. The wounded part of the body then returns to its normal appearance with no trace of the ritual. This is what is referred to as the efficacy of Mamala Oil. The oil acts as both a method of healing and symbol of the greatness of the Creator, which has been proven to the people Mamala since they first began the construction of their mosque, and reinforced by the healing of their wounds today. This is in line with Butler arguments that "performance presupposes a preexisting subject, performs contests the very notion of the subject" (Salih, 2002: 63). Hence, it can be interpreted that the pukul sapu ritual is an arena of identity performance and also an experience to prove the efficacy of Mamala Oil, which is a representation of the presence of Allah's power in the history of Mamala. There are two things that can be seen from this performance. The first is that it serves as an arena or medium for Mamala people's identity, and the second is that it is employed to prove the efficacy of Mamala Oil.

The flagellation ritual carried out by young Mamala Muslims, which is a form of cultural inheritance from their ancestors blending tradition or custom and religious values, has constructed the collective identity of Mamala society. This is in line with Berger's ideas (1990: 4) on the dialectical process.

\section{From Ramadhan, ledul Fitri, and the $7^{\text {th }}$ Day of Syawal, to Flagellation}

Reciprocal flagellation in Mamala is related to the belief of those villagers who embraced Islam. This is in accordance with the narrative of the former King of Mamala, who said that:

The tradition of pukul sapu takes place during the momentum of religious rituals starting from Ramadhan, Iedul Fitri, and finally the $6^{\text {th }}$ day of Syawal, on which the attraction of the flagellation ritual is performed. It has strong religious reasons. There is a Hadith stating that that whoever fasts in the month of Ramadhan, plus six days in Syawal will be regarded as fasting for a whole year. ${ }^{18}$

The interpretation of the hadiths is that those who add six days of fasting to the end of Ramadhan, a tradition known as Syawal, can be regarded as succeeding in keeping the discipline of fasting, avoiding immoral acts, and defeating lust. Thus, it turned out that those people who are still able to survive should be celebrated massively as victorious. Besides, it is also a precise momentum to test the efficacy of Mamala Oil. ${ }^{19}$

The above description is also in accordance with the statement of the former King of Mamala: "Ramadhan, Iedul Fitri, and the $7^{\text {th }}$ day of Shawal was bridged by the $1-6^{\text {th }}$ of Shawal. After Muslims fast for 30 days in Ramadhan, and then celebrate their victories at Iedul Fitri, the $1^{\text {st }}$ day of Syawal, they are required to carry out an optional six days' worth of fasting in the month of Syawal. At the peak, on the $7^{\text {th }}$ day of Syawal, they have managed to refrain from all earthly things, so that their fasting, from Ramadhan until the $7^{\text {th }}$ day of Syawal, has the same value as a full year of fasting."

Here, we see clearly that the tradition of pukul 
sapu held on the $7^{\text {th }}$ day of Syawal has two meanings. First, it is considered the expression of victory over the fasting in Ramadhan plus six days of sunnah (optional) fasting. Mamala society expresses the victory and claims the reward of the promised full year's worth of fasting with the flagellation ritual. Second, it also aims to prove the efficacy of Mamala Oil. The right time to test the efficacy of Mamala Oil, according to the former King of Mamala, is after the completion of six days sunnah fasting in Syawal.

This shows the integration of religion and culture, both of which are complementary. The culture of reciprocal flagellation is used as a method to show the efficacy of Mamala Oil as a symbol of Allah's presence in the history of Mamala society. This process is in line with Geertz's suggestion (1994: 4 ), namely the dialectical process that relates two important elements in society. It becomes a strength for the Mamala community in a form of specific characteristics of their form of Islam, which differs from other Muslim communities. It means that the ritual and Mamala Oil are together the symbol as well as the attribute of Mamala society that made them solid and authentic. The attribute, solidity and authenticity, according to Jenkins (2008: 134), function as community symbolization. Therefore, the pukul sapu ritual becomes the solidarity umbrella for Mamala people, binding all generations of the villagers and compelling them to come back to their home every year.

The pukul sapu ritual can be interpreted as an expression arena of their religious identity, as it is a distinctive tradition among the Muslim communities in the region. This actually shows the boundaries of identity, similar to Jenkins's argument (2008: $135)$ that when people are aware of their cultural differences and stay on the local sense of differences, it is called the boundaries of culture. In other words, this special moment for Mamala society also functions to describe the victory expressions over the things that are regarded as being profane. Therefore, the tradition had been used as a means of educating children, even though there is a violent aspect to it, namely the striking of the body. Then it is implemented on the $7^{\text {th }}$ day of Syawal as a way of always remembering the greatness and mercy of Allah SWT.

Here, we also see that there are important numbers like six and seven and the month of Syawal, which in Islam have religious value and meaning because of these numbers and this month have been taught by the prophet as the time to carry out sunnah (optional) fasting. For Muslims, what have been shown as sunnah by the prophet become highly recommended practices to implement even if they are not mandatory. Although it is unlike fasting in the month of Ramadhan, fasting in the month of Syawal remains a great desire for Muslims to accomplish because it relates to perfection. This reveals the powerful influence of symbols in the ritual process and belief systems of religion and society. According to Turner (1982: 19), the symbol is the smallest unit of ritual sounding the certain wealth of behavior. The symbol is also the last unit of a particular structure in the context of religious rituals. Turner in Wolanin (1978) said that rituals can be seen in the symbolic acts and symbolic articles that emphasize the interpreted object or material. Therefore, the pukul sapu ritual in Mamala can be seen as the arena and symbols to reveal the meaning of the presence of Allah SWT in the history of the village.

\section{CONCLUSION}

From the discussion on the ritual reciprocal flagellation as the construction medium of social identity in Mamala, it can be concluded that: the social identity of Mamala society in terms of both custom and religion is formed through the dialectical process or contact with outer elements. Thus, it can be confirmed that identity is the result of an adaptation, relations, and negotiations process, which Geertz called dialectic. Here, we see that identities are always searching and adapting to certain conditions and situations.

Identity always changes in the sense that it always adapts with the development of time and knowledge that always continue to progress. In other words, identity always undergoes a transformation of values that always brings ideas and soft concepts in nature, although there are still principles maintained. Therefore, the adaptation process always prioritizes interests and needs. It is associated with the sanctity and holiness concept of a woman involved in the process of cooking oil.

Mamala's social identity, reflected in the pukul sapu ritual, is a media construction, associated with their religious identity as Muslims that uphold Islamic values, and at the same time being dialectical with the existing custom or culture. This is to give meaning to their religious value in their belief system surrounding Allah SWT, whom they believe appears in their history. The flagellation ritual is also a medium to construct a social identity of Mamala men who are courageous, 
patient, perseverant, and confident. They also believe that there will always be solutions to any problems, because the problem itself will not be more powerful than their strengths. The ritual also becomes the arena of Mamala women's identity construction. It is believed that they are always loyal to their domestic responsibilities. Although it is local business, it is nevertheless the most important part considering their position in the ritual, since they were commissioned in cooking the oil.

The pukul sapu ritual becomes the arena of historical preservation of the ancestors' culture. From the ritual, we can see that the power is moving, working, but it concentrates in certain agencies. This started from the process of forming Mamala Oil, in which the negotiating process only involved three figures, even the prayer in the process of making the oil was only known to Imam Tuni as the agent other than the King. This proves that power only revolved and focused on specific points, so that cultural preservation of the custom also becomes a place of historical preservation and its operation of power.

\section{ENDNOTES}

1) The concept of monotheism in Islam establishes that only one God is to be recognized.

2)I discovered this information when I interviewed the former King of Mamala, dated 17 July 2015.

3 )The result of an interview with the former King of Mamala, dated 17 July 2015.

4)The result of an interview with the former King of Mamala, dated 17 July 2015.

5)The result of an interview with Mr. Jalal, dated 12 July 2015.

6)The result of interviews with the former King of Mamala (dated 17 July 2015), Mr. Jalal (dated 12 July 2015), and Mr. Haris (dated 14 July 2015).

7)Hai Imam Tuni, Ambilah minyak kelapa, bacalah ayat berikut ini (Al-Quran dari surah Al-fatiha), kemudian oleskan minyak itu pada bagian kayu yang patah, selanjutnya tutup dan ikat dengan kain putih selama beberapa saat, buka kembali dan lihatlah apa yang kau inginkan.

8)The result of an interview with Mr. Jalal (dated 12 July 2015), and Mr. Farid, who is the one of Mamala Country Youth and graduate of the Tarbiah Faculty, IAIN Ambon (dated 14 July 2015).

9)Doxa is categorizes truth enforced to be universal truth.

10) The result of an interview with the former King of Mamala, dated 17 July 2015.

11) The result of an interview with the former King of
Mamala, dated 17 July 2015.

12) The result of an interview with the former King of Mamala, dated 17 July 2015.

13)Jika Allah SWT tidak merestui maka semua usaha utuk membangun masjid tidak akan terlaksana, bahkan tidak akan ada mimpi yang Allah berikan dan minyak tersebut tidak akanada artinya.

14) The result of an interview with the former King of Mamala, dated 12 July 2015.

15) The result of an interview with Mr. Jalal, dated 12 July 2015.

16) The result of an interview with one of the customary figures, dated 12 July 2015.

17) The result of an interview with Mr. Jalal, dated 12 July 2015.

18) Menurutbapak Jalal, pada zaman datuk-datuk sapu lidi dipakai untuk mendidik anak-anak karena ketika dipukul rasanya sakit dan bisa berdarah.

19) The result of an interview with one of the customary figures, dated 12 July 2015.

20)Ada juga pendapat lain yang mengatakan bahwa penggunaan sapu lidi sebagai alat menguji kehasiatan minyak Mamala, oleh karena apda zaman dahulu raja negeri Mamala membujuk anak perempuanya yang bernama Fatimah saat menangis dengan berbagai cara namun tidak berhasil. setelah dia melihatadegan pukul sapu maka anak tersebut menjadi diam.

21)The result of an interview with the former King of Mamala, 17 July 2015.

22)Ada pedapat lain yang juga mengatakan bahwa penggunaan sapu lidi untuk menguji kehasiatan minyak Mamala oleh karena sapu lidi bagi leluhur dianggap sebagai tanaman yang bertuah. Ada kekuatan yang dasyat seperti contoh saat sapu lidi digunakan untuk memukul bisa membangkitkan rasa sakit yang luar biasa dan mengeluarkan darah.

23)The result of an interview with the former King of Mamala, dated 17 July 2015.

24)Tradisi pukul sapu Lidi berlangsung dalam suatu momentum ritual keagamaan mulai dari Ramadhan, idul fitri 6 Syawal dan tepat 7 Syawal dilakukan atraksi pukul sapu lidi, karena itu tardisi tersebut memiliki alasan religius yang kuat. Ada hadits yang mengatakan bahwa barang siapa yang berpuasa dalam satu bulan dalam bulan Ramadhan, ditambah 6 hari dalam bulan Syawal memiliki nilai yang sama dengan puasa setahun. 25)The result of an interview with Mr. Haris, dated 12 July 2015.

\section{REFERENCES}

Andries, Flavius Floris (2014). Identitas Jemaah Ahmadiyah Indonesia Dalam Konteks Multikultural. Humaniora, Vol 26, No 2. 
Barker Chris (2006). Cultural Studies and Discourse Analysis a Dialogue on Language and Identity, London: Sage Publication.

Bell. Catherine (1997). Ritual: Perspective and Dimensions. New York: Oxford University Press.

Bell Catherine (1992). Ritual Theory, Ritual Practices. Oxford: Oxford University Press.

Berger, Petter and Thomas Luckman (1994). The social Construction of Reality: a Treatise in the Sociology of Knowledge. New York: Penguin Books.

Boven, Theodora Van (2016). Religious Education for Tolerance. Graduate Thesis, Radboud University, Nijmegen.

Buttler, Judith (2004). Undoing Gender. New York and London, Routledge. (1990). Bodies that Matters. New York and London: Routledge.

Cooley, Frank Leonard (1961). Altar and Throne, Dissertation. Yale University, USA.

Cresswell, Jhon W. (2012). Educational Research: Planning, Conducting, and Evaluating Quantitative and Qualitative Research. New Jersey: Person Education, Inc.

Durkheim, Emille (1994). The Elementary Forms of Religious Life Karen E. Fields (Trans.). New York: the Free Press,

Geertz. Geertz (1992). Interpretation of Culture. Princeton: Basic Book.

Giddens, Anthoy (1989). Sociology. Cambridge: Polity Press.

Hewit, Jhon P. (2003). Self and Society, A Symbolic
Interactionist Social Psychology. Boston: A7B Press.

Jenkins. R. (2008). Social Identity. New York: Routledge. Lawler. S. (2008). Identity: Sociological Perspective. Malden (MA): Polity Press.

Maram. R. Rafael. (2000). Kebudayaan, Dalam Perspektif Ilmu Budaya Dasar. Jakarta: PT Rineka Cipta.

Pals Daniel, L (2006). Eight Theories of Religions. New York: Oxford University Press.

Plumer. K. (1999). Identity, In William Outhwhite dan Tom Bottemore (eds). The Blackwell Dictionary of Twentieth Century Social Through. Oxford: Blackwell Publisher

Turner Victor, W. (1982). From Ritual to Theatre, New York Performing arts. Cornel University Press.

Wolanin. Adam (1978). Rite, Ritual Symbol and Their Interpretation in the Writing of Victor Turner. Rome: Facultate Theologiae Pontiviciae

Liliweri. Alo (2007). Makna Budaya Dalam Komunikasi antar budaya. Yogyakarta: LKIS.

Taylor, E.B. (1970). Religion in Primitive Culture. New York: Haprer and Row Publisher.

Van Meijl, T and Meidema.J. (eds.) (2004). Shifting Images of Identity in the Pacific. Leiden: KITLV Press.

Yusuf, Mohamad (2013). When Culture Meets Religion: The Muludan Tradition in the Kanoman Sultanate, Cirebon, West Java. $A L$ ALBAB - Borneo Journal of Religious Studies (BJRS), Vol. 2 (1). 